\title{
Incidence of injuries confused with pressure injuries in oncology intensive care unit
}

\section{Incidência das lesões confundidoras da lesão por pressão em unidade de terapia intensiva oncológica}

\section{Incidencia de las lesiones confundidoras de la lesión por presiónen unidad de terapia intensiva oncológica}

\author{
José Ferreira Pires Júnior ${ }^{1,2^{\star}}$, Eline Lima Borges ${ }^{1}$, Josimare Aparecida Otoni Spira $^{2}$
}

ORCID IDS

Pires Júnior JF (DD https://orcid.org/0000-0002-6019-0198

Borges EL (D) https://orcid.org/0000-0002-0623-5308

Spira JAO (D) https://orcid.org/0000-0002-6577-0394

\section{HOW TO CITE}

Pires Júnior JF, Borges EL, Spira JAO. Incidence of injuries confused with pressure injuries in oncology intensive care unit. ESTIMA, Braz. J. Enterostomal Ther., 17: e0219. https://doi.org/10.30886/estima. v17.667 IN

\begin{abstract}
Objectives: Estimate the incidence of the confounding lesions $(\mathrm{CL})$ with pressure injuries in an intensive care unit of an oncology hospital, to characterize the patients and the confused injuries. Methods: Prospective cohort study conducted in an adult intensive care unit of an oncology hospital in Belo Horizonte, Minas Gerais. The sample consisted of 67 patients who met the inclusion criteria. The data were collected during the period of one month by single researcher stomatherapist and registered in the form prepared for this purpose. The study was approved by the Research Ethics Committee. Results: 58.1\% were women, $65.1 \%$ were elderly, $51.2 \%$ were white, with gastrointestinal cancer predominating, $71.6 \%$ were using adjuvant chemotherapy, with below-normal body mass index, 100\% had urinary incontinence or fecal and diaper use. The incidence of these injuries was 35.8\%, and the average time for their onset was 11 days after admission. Most patients had skin changes such as maceration, peeling, erythema, dehydration, and edema. Conclusion: We can conclude that the incidence of confused injuries is high in oncology patients admitted to intensive care units. It was possible to describe the demographic and clinical profile of the patients of the sample and to characterize the injuries and the skin around them.
\end{abstract}

DESCRIPTORS: Intensive care units; Medical Oncology; Wounds and injuries; Incidence; Pressure ulcer; Stomatherapy.

1.Universidade Federal de Minas Gerais - Escola de Enfermagem - Departamento de Enfermagem Básica - Belo Horizonte/MG - Brazil.

2.Instituto Mário Penna - Hospital Luxemburgo - Belo Horizonte/MG - Brazil.

Corresponding author: piresjuniorr@hotmail.com

Received: Nov. 21, 2018 | Accepted: Feb. 25, 2019 


\section{RESUMO}

Objetivos: Estimar a incidência das lesões confundidoras (LCS) da lesão por pressão (LP) em unidade de terapia intensiva (UTI) de um hospital oncológico, caracterizar os pacientes e as LCS. Métodos: Estudo de coorte prospectivo realizado em UTI de hospital oncológico de Belo Horizonte, estado de Minas Gerais. A amostra foi composta por 67 pacientes que atenderam aos critérios de inclusão. Os dados foram coletados durante o período de um mês por único pesquisador estomaterapeuta e registrado em formulário elaborado para esse fim. O estudo foi aprovado pelo comitê de ética em pesquisa. Resultados: 58,1\% eram mulheres, 65,1\% idosos, 51,2\% brancos, com predominância de câncer gastrointestinal, 71,6\% em uso de quimioterapia adjuvante, com índice de massa corporal (IMC) abaixo da normalidade, 100\% apresentavam incontinência urinária ou fecal e em uso de fraldas. A incidência das LCs foi 35,6\%, com predomínio da dermatite associada à incontinência (DAI). O tempo médio para o surgimento foi de 11 dias. Conclusão: A incidência das LCS foi elevada e infere-se que possa ter relação com a presença do câncer e o tratamento neoadjuvante, o que requer estudos específicos para elucidar o fato.

DESCRITORES: Unidades de terapia intensiva; Oncologia; Ferimentos e lesões; Incidência; Lesão por pressão; Estomaterapia.

\section{RESUMEN}

Objetivos: estimar la incidencia de las lesiones confundidoras (LC) de la lesión por presión en unidad de terapia intensiva (UTI) de un hospital oncológico, caracterizar a los pacientes y las LC. Métodos: estudio de cohorte prospectivo realizado en UTI de hospital oncológico de Belo Horizonte, Minas Gerais. La muestra fue compuesta por 67 pacientes que atendieron los criterios de inclusión. Los datos fueron recolectados durante el período de un mes por único investigador estomaterapeuta y registrado en formulario elaborado para este fin. El estudio fue aprobado por el Comité de Ética en Investigación. Resultados: 58,1\% eran mujeres, 65,1\% ancianos, $51,2 \%$ blancos, con predominio del cáncer gastrointestinal, 71,6\% en uso de quimioterapia adyuvante, con índice de masa corporal por debajo de la normalidad, 100\% presentaban incontinencia urinaria o fecal y en uso de pañales. La incidencia de las LC fue 35,6\% con predominio de la dermatitis asociada a incontinencia. El tiempo medio para la aparición fue de 11 días. Conclusión: la incidencia de las LC fue elevada y se infiere que pueda tener relación con la presencia del cáncer y el tratamiento neoadyuvante, lo requiere estudios específicos para elucidar este hecho.

DESCRIPTORES: Unidades de cuidados intensivos; Oncología médica; Heridas y lesiones; Incidencia; Úlcera por presión; Estomaterapia.

\section{INTRODUCTION}

Since the beginning of the 21st century, skin lesions, called cutaneous lesions or simply wounds, have received special attention from health professionals due to their high prevalence and incidence. In addition, they cause a socioeconomic impact for patients, families, health services and society in general and are responsible for negatively affecting the health and quality of life of people affected ${ }^{1}$.

In the group of lesions that affect the hospitalized patients, we highlight the pressure injury (PI), called pressure ulcer until April 2016, when the nomenclature was changed by the National Pressure Ulcer Advisory Panel (NPUAP) ${ }^{2,3}$. On that same date, the concept was revised and PI was considered to be localized damage to the skin and/or underlying soft tissue, usually on bone prominence, or may still be related to medical equipment or other devices. The lesion may present as intact skin or as an open ulcer and can be painful. Occurs as a result of exposure to pressure or shear pressure. Tolerance of soft tissue to pressure and shear can also be affected by microclimate, nutrition, perfusion, associated diseases, and tissue condition ${ }^{2,3}$.

The multiplicity of risk factors related to the development of PI is, concurrently, with other types of skin lesions. This situation often leads professionals to confuse the presence of PI with cutaneous lesions of other causes. Stage 2 PI is defined as partial skin loss with dermal exposure. Because it appears to be moist, pink or red in color, or as an intact or ruptured blister, this stage is mistaken for incontinenceassociated dermatitis (IAD), friction lesion (FL), and injury related to medical adhesives ${ }^{3}$. In the present study, these lesions will be called confounding lesions (CLs) for the occurrence of PI. Some professionals tend to classify skin lesions as PI. This fact results in the lack of institutional records of CLs.

In Brazil, from the publication of Ordinance No. 529 of April 1,2013, by the Ministry of Health ${ }^{4}$, the PI is considered an adverse event, that is, an incident that results in harm 
to the patient; in addition, its occurrence is of monthly compulsory notification.

Since 2009, the guidelines published by NPUAP and the European Pressure Ulcer Advisory Panel (EPUAP) recognize the IAD as a distinct condition of PI and recommend that care professionals be trained to carry out the differential diagnosis $^{2}$.

IAD is a type of dermatitis associated with moisture defined as the prolonged exposure of the skin to the effluent (urine, feces, exudate, and sweat) with erythema and surface edema, and may be accompanied by erosion, flaccid with serous exudate or secondary infection. It mainly affects the perineal, perianal and inguinal regions ${ }^{5}$.

Another type of CL is FL, considered a traumatic injury that occurs more frequently in the upper and lower extremities of the elderly, resulting from friction or the combination of friction and shear. This damage causes separation of the epidermis from the dermis and results in a partial thickness wound or causes total separation of the epidermis and dermis from the underlying structures, resulting in a full thickness wound ${ }^{6}$.

The third lesion in the CL group is the lesion related to medical adhesives, the definition of which is the occurrence of hyperemia and/or other manifestation of skin alterations, such as gallbladder, flicten, erosion and rupture, persisting for more than 30 minutes after removal of the medical adhesive. In general, these lesions are related to mechanical and chemical trauma from the use of these medical adhesives ${ }^{7}$.

Although it is an old problem, it is inferred that the occurrence of CLs has increased with increasing longevity of the Brazilian population and the incidence of chronicdegenerative diseases, especially cancer. This context raises specific studies related to these lesions, common in clinical practice, but little studied. The results can contribute to the systematization of CL nomenclature and encourage discussion about prevention and treatment.

In clinical practice, in several health institutions in Brazil, there are still doubts about the causes of the development of CLs and the factors that delay their healing process. Because of the complexity presented by oncology patients, especially those hospitalized in an intensive care unit, the question arises: what is the incidence of LCs and what are the characteristics of the patients who develop them?

Studies on the occurrence of friction lesions, IAD and those related to medical adhesives are scarce, including the epidemiological ones, concerning the incidence and prevalence of these lesions, and they do not exist in the databases when they are related to critically ill cancer patients.

This finding fosters the need for the development of research based on the critical patients of a cancer hospital who, due to the disease itself and as a result of the treatments demanded, are inferred to be at increased risk for the onset of these lesions. Therefore, the objectives of this study were to estimate the incidence of CLs of PI in an intensive care unit (ICU) of a cancer hospital and to characterize patients and LCs.

\section{METHODS}

This is a pilot study of prospective cut. All the patients admitted to the ICU at a large philanthropic oncology hospital in Belo Horizonte, state of Minas Gerais, were considered.

The population consisted of 144 patients who were hospitalized in the ICU in the month of the study and the intentional kind of sample consisted of 67 patients who met the inclusion criteria: age equal to or greater than 18 years, remaining in the ICU for a minimum period of 48 hours after the first evaluation, thus allowing the follow up with two consecutive skin evaluations during the period of data collection. It was also considered inclusion criteria to present a risk factor for at least one CL; urinary, fecal or double incontinence for IAD; edema for FL; adhesive attached to any part of the body, regardless of intent, for medical adhesive related injury.

The data were collected by a single stomatologist researcher during the period of one month. In order to fill out the data collection instrument, information extracted from the electronic medical record was used and daily inspection of the patients' skin at the moment of bed hygiene, in order to avoid further discomfort to patients.

In order to meet the proposed objectives, the following study variables were chosen: CL (IAD, FL, adhesive lesion) evaluated for the type, number, location and characteristics of the surrounding skin; demographic variables (age, sex and race/ethnicity); clinics [illness that led to ICU admission; associated diseases, habits harmful to health (alcoholism and smoking); medications used in the ICU; neoadjuvant treatment; BMI; hemoglobin; glycemia], presence of edema, use of adhesive (microporous adhesive tape or other type of adhesive), type of incontinence (urinary, 
fecal, mixed), devices for incontinence control (external urinary catheter, intermittent bladder catheter, delayed bladder catheter, disposable diaper, intestinal and urinary stomatal collection device), skin care (ointment based on zinc oxide, essential fatty acids, bepantol, nystatin, ketoconazole), skin cleansing (water + neutral soap).

The mean, median and standard deviation (SD) were used to describe the numerical variables. The categorical variables were summarized by absolute and relative frequencies and 95\% confidence interval $(95 \% \mathrm{CI})$, when pertinent.

To calculate the incidence, we considered the absolute number of cases of people who developed CL during the study period divided by the number of patients with risk factor (risk factor for at least one CL: urinary, fecal or double incontinence for IAD; edema to FL, adhesive affixed to any part of the body, regardless of its intention, for medical adhesive related injury) to CL from IAD, FL and injury related to medical adhesive interned in the same period multiplied by 100 .

The research project obtained approval from the institution's ethics committee field of study under opinion No. 2,072,922. The research complied with the terms of Resolution No. 466 of December 12, 2012, of the National Health Council. The Free and Informed Consent Form (TCLE) was signed by the patient or his/her legal representative to participate in the study.

\section{RESULTS}

The study consisted of a follow-up of 67 patients. Of these, 24 developed at least one type of CL, corresponding to the general incidence of $35.6 \%$. Considering each type of CL, an incidence of $20.8 \%$ was found for IAD, $5.9 \%$ for FL and $8.9 \%$ for lesion by medical adhesive. A description of the demographic variables of the participants is given in Table 1.

All patients in the sample had cancer, with the most frequent being gastrointestinal (20/29.9\%), prostate $(12 / 17.9 \%)$, breast (9/13.4\%) and cervix 8/11.9\%). To control the disease, $71.6 \%$ used chemotherapy exclusively, $10.5 \%$ radiotherapy and $17.9 \%$ underwent chemotherapy and radiation therapy.

The main cause of ICU admission was an acute respiratory failure (25\%). The most frequent associated diseases presented by the participants were systemic hypertension (32.8\%), diabetes mellitus (28.3\%), heart disease (14.9\%) and depression (13.4\%).

Regarding the use of medications, $11.9 \%$ did not use. The other participants used one or more medications, such as antihypertensive or diuretic (33.8\%), sedatives (32.8\%), analgesics (28.8\%), among others.

The majority of the participants presented a body mass index (BMI) below normality (38/56.7\%) with a mean of $16.8 \mathrm{~kg} / \mathrm{m}^{2}( \pm 2.1)$, serum hemoglobin below $12.5 \mathrm{~g} / \mathrm{dL}$ $(49 / 73.1 \%)$ with a mean of $9.3( \pm 1,5)$ and capillary glycemia greater than $126 \mathrm{mg} / \mathrm{dL}(35 / 52,2 \%)$ with an average of $167 \mathrm{md} / \mathrm{dL}( \pm 37)$.

Table 2 shows the distribution by lesion type of the 24 patients who presented CL.

The time to onset of CL varied from one to 30 days after ICU stay, with a mean of $11.0( \pm 13.9)$ days and a median of 5.0 days. The majority of the lesions (66.7\%) arose with a time less than 10 days, mainly by medical adhesive and friction.

Table 1. Demographic characteristics of the participants $(n=67)$, Belo Horizonte, state of Minas Gerais, Brazil, 2018.

\begin{tabular}{|c|c|c|c|c|c|}
\hline \multirow{2}{*}{ Variable } & \multirow{2}{*}{ Category } & \multicolumn{2}{|c|}{ Confounding lesions $\mathrm{n}(\%)$} & \multirow{2}{*}{$\begin{array}{c}\text { Mean } \\
\text { (Standard deviation) }\end{array}$} & \multirow{2}{*}{ Medium } \\
\hline & & No $(n=43)$ & Yes $(n=24)$ & & \\
\hline \multirow{2}{*}{ Gender } & Female & $25(58.1)$ & $15(62.5)$ & \multirow{2}{*}{-} & \multirow{2}{*}{-} \\
\hline & Masculino & $18(41.9)$ & $9(37.5)$ & & \\
\hline \multirow{4}{*}{ Idade (anos) } & $18-30$ & $1(2.3)$ & $0(0.0)$ & \multirow{4}{*}{$68.3(12.4)$} & \multirow{4}{*}{71.0} \\
\hline & $31-59$ & $14(32.6)$ & $5(20.8)$ & & \\
\hline & $60-79$ & $24(55.8)$ & $15(62.5)$ & & \\
\hline & Over 80 & $4(9.3)$ & $4(16.7)$ & & \\
\hline \multirow{3}{*}{ Race/ethnicity } & White & $22(51.2)$ & $12(50.0)$ & \multirow{3}{*}{-} & \multirow{3}{*}{-} \\
\hline & Black & $7(16.3)$ & $5(20.8)$ & & \\
\hline & Brown & $14(32.5)$ & $7(29.2)$ & & \\
\hline
\end{tabular}


The majority of CL were IAD (14/58.3\%), located in gluteal region $(9 / 64,3 \%)$, perianal $(4 / 28,6 \%)$ and perigenital $(1 / 27,1 \%)$. The six lesions with medical adhesive were on the upper limbs and the four friction lesions were on the calf (2), scapula (1) and hemithorax (1).

Regarding the characteristics of the surgical tapes used by the participants, the microporous tape was used by all patients and four presented lesions by medical adhesive. Of the six in use of transparent film, two evolved with injury by medical adhesive.

All study participants had at least one type of incontinence, being $44.8 \%$ (30) mixed, $32.8 \%$ (22) urinary and $22.4 \%$ (15) fecal, and 14 developed IAD even with the use of a device

Table 2. Type of confounding lesion of the sample $(n=24)$, Belo Horizonte, state of Minas Gerais, Brazil, 2018.

\begin{tabular}{|c|c|c|}
\hline Variable & Category & n (\%) \\
\hline \multirow{2}{*}{$\begin{array}{l}\text { Injury by medical } \\
\text { adhesive }\end{array}$} & Yes & $6(25.0)$ \\
\hline & No & $18(75.0)$ \\
\hline \multirow{2}{*}{$\begin{array}{l}\text { Injury associated with } \\
\text { incontinence }\end{array}$} & Yes & $14(58.3)$ \\
\hline & No & 10 (41.7) \\
\hline \multirow{2}{*}{ Friction lesion } & Yes & $4(16.7)$ \\
\hline & No & $20(83.3)$ \\
\hline
\end{tabular}

for handling. Table 3 shows the distribution of devices for incontinence control and characteristics of intestinal and urinary elimination.

The products used by participants in the skin of the diaper region for the prevention of dermatitis are presented in Table 4. It was noticed that some patients used more than one product for prevention of IAD.

Cleansing the skin for diaper replacement was performed with mild soap and water. For skin protection, most used essential fatty acids (57/85\%).

Patients who developed IAD were using skin protection products: 14 (100\%) essential fatty acids and 9 (64.3\%) zinc oxide. According to practitioners, it is common to carry out the mixing of the two products for application in the diaper region.

Considering the 24 participants who presented CL, one maintained intact skin around the lesion. The remaining 23 (87.5\%) presented some type of alteration, such as maceration $(8 / 33,3 \%)$, desquamation (6/25\%), erythema $(5 / 20,8 \%)$ and dehydration 4/16.7\%). Local edema was present in $15(62.5 \%)$ participants, with a score of $1+(6 / 40 \%), 2+$ $(5 / 33,3 \%)$ and $3+(4 / 26,7 \%)$.

Table 3. Devices to control incontinence and characteristics of intestinal and urinary elimination $(n=67)$, Belo Horizonte, state of Minas Gerais, Brazil, 2018.

\begin{tabular}{|c|c|c|c|}
\hline \multirow{2}{*}{ Incontinence control devices } & \multirow{2}{*}{ Category } & \multicolumn{2}{|c|}{ Incontinence Associated Disease (\%) } \\
\hline & & No $(n=53)$ & Yes $(n=14)$ \\
\hline \multirow{2}{*}{ External urinary catheter } & Yes & $5(9.4)$ & $1(7.1)$ \\
\hline & No & $48(90.6)$ & $13(92.9)$ \\
\hline \multirow{2}{*}{ Delayed bladder catheter } & Yes & $33(62.3)$ & $5(35.7)$ \\
\hline & $\mathrm{No}$ & $20(37.7)$ & $9(64.3)$ \\
\hline \multirow{2}{*}{ Disposable diaper } & Yes & $53(100.0)$ & $14(100.0)$ \\
\hline & No & $0(0.0)$ & $0(0.0)$ \\
\hline Number of disposable diaper & 4 & $42(79.3)$ & $12(85.7)$ \\
\hline changes per day & 6 & $11(20.7)$ & $2(14.3)$ \\
\hline \multirow{2}{*}{$\begin{array}{c}\text { Collecting device for intestinal } \\
\text { ostomies }\end{array}$} & Yes & $3(5.6)$ & $1(7.1)$ \\
\hline & $\mathrm{No}$ & $50(94.4)$ & $13(92.9)$ \\
\hline \multirow{4}{*}{$\begin{array}{l}\text { Collecting device for urinary } \\
\text { ostomies }\end{array}$} & Yes & $2(3.7)$ & $2(14.3)$ \\
\hline & $\mathrm{No}$ & $51(96.3)$ & $12(85.7)$ \\
\hline & 0 & $2(3.8)$ & $0(0.0)$ \\
\hline & 1 & $21(39.6)$ & $0(0.0)$ \\
\hline \multirow[t]{4}{*}{ Stool episodes per day } & 2 & $20(37.7)$ & $1(7.1)$ \\
\hline & 3 & $8(15.1)$ & $(21.4)$ \\
\hline & $>4$ & $2(3.8)$ & $10(71.5)$ \\
\hline & Pasty & $33(62.3)$ & $0(0.0)$ \\
\hline \multirow[t]{2}{*}{ Stool consistency } & Semi-pasty & $11(20.7)$ & $2(14.3)$ \\
\hline & Liquid & $9(17.0)$ & $12(85.7)$ \\
\hline
\end{tabular}


Table 4. Products used in the skin care institution for the prevention of incontinence-associated dermatitis (IAD) $(n=67)$, Belo Horizonte, state of Minas Gerais, 2018.

\begin{tabular}{|c|c|c|c|}
\hline \multirow[t]{2}{*}{ Variable } & \multirow[t]{2}{*}{ Category } & \multicolumn{2}{|c|}{$\begin{array}{c}\text { Dermatite associada à } \\
\text { incontinência (\%) }\end{array}$} \\
\hline & & No $(n=53)$ & Yes $(n=14)$ \\
\hline \multirow{2}{*}{ Zinc oxide } & Yes & $28(52.8)$ & $9(64.3)$ \\
\hline & No & $25(47.2)$ & $5(35.7)$ \\
\hline Essential Fatty & Yes & $43(81.1)$ & $14(100.0)$ \\
\hline Acids & No & $10(18.9)$ & $0(0.0)$ \\
\hline \multirow{2}{*}{ Nystatin } & Yes & $5(9.4)$ & $3(21.4)$ \\
\hline & No & $48(90.6)$ & $11(78.6)$ \\
\hline \multirow{2}{*}{ Ketoconazole } & Yes & $3(5.6)$ & $1(7.2)$ \\
\hline & No & $50(94.4)$ & $13(92.8)$ \\
\hline \multirow{2}{*}{ Dexpantenol } & Yes & $20(37.7)$ & $1(7.2)$ \\
\hline & No & $33(62.3)$ & $13(92.8)$ \\
\hline
\end{tabular}

\section{DISCUSSION}

It is noteworthy that in the databases there are no publications regarding the incidence and prevalence of CLs - IAD, FL, and injury related to medical adhesive considered together. In this study, the estimated incidence of these lesions was $35.8 \%$, with an average of $11.0( \pm 13.9)$ days and a median of 5.0 days for its appearance. These data are surprising, therefore, these lesions can no longer be ignored by clinical practice professionals and managers of hospital institutions.

A prospective cohort study by Konya et al. ${ }^{8}$ with 155 elderly individuals aged 65 years or over in a long-stay institution found a $15.5 \%$ incidence of medical adhesive damage. A prospective cohort study in a vascular clinic over a period of three months, with a follow-up of 120 patients, found a $5.8 \%{ }^{9}$ incidence of a lesion by medical adhesive, similar data compared to this study. Despite the differences between the ICU where the study was carried out, the long stay institution and the vascular clinic, the studies carried out in the three scenarios had a predominance of elderly participants, over 60 years old, and with a degree of dependence, making it difficult to self care, thus increasing the chance of CLs occurrence.

In a systematic review study on friction injuries, published in 2015, no primary studies were found in critically ill patients ${ }^{10}$, only studies of the prevalence of friction injuries performed in long-term institutions. A study carried out in long-term institutions in Canada, with 113 elderly, identified a prevalence of FL of $22 \%{ }^{11}$.
In a study conducted in Japan, prevalence ranged from 3 to $9 \%$ among a total of 410 people aged $73-87$ years $^{12}$. In Brazil, a study with cancer patients obtained a prevalence of FL of $3.3 \%$ and the majority were female elderly ${ }^{13}$.

Medical adhesives and bandage dressings have been identified as the main culprits for medical adhesive injuries at the extremes of age. Although elderly and newborns constitute the largest risk groups, there are other groups that are subject to fragilities, such as critically ill individuals, palliative care and anti-neoplastic treatment ${ }^{10}$.

All patients in the sample had cancer and had undergone neoadjuvant treatment, either with chemotherapy, radiotherapy or chemotherapy associated with radiotherapy. It is known that the use of antineoplastic agents causes changes in the epidermis, in the dermis and in the synthesis of collagen. Cutaneous reactions are frequent in these individuals, in addition to the delay in the healing process ${ }^{1}$.

Important data identified in the participants was the prevalence of malnutrition. Because it is cancer patients, this data is not surprising, since cancer alters the physiological functions of the body and causes an imbalance in metabolism, in which the breakdown of proteins and lipids is accelerated, while the synthesis of muscle proteins is diminished. These changes contribute to increased energy expenditure and may result in progressive weight loss ${ }^{14}$. The majority presented changes in serum hemoglobin and capillary glycemia rates.

Serum hemoglobin and BMI are simple nutritional markers and should be continuously checked in patients at nutritional risk in order to reduce future complications. Healing is a dynamic process, with direct influence of nutritional status. Tissue repair and remodeling need sufficient supplementation of precursors, cofactors, and energy source. Malnutrition adversely affects the clinical evolution of individuals by increasing hospitalization time, the incidence of postoperative complications, such as infections and retardation in wound epithelialization, as well as increasing the mortality rate ${ }^{15}$. Clinical conditions such as cachexia/anorexia, malnutrition, anemia, metabolic syndromes, advanced age, and circulatory disorders compromise skin health ${ }^{16}$.

The main reason for hospitalization in ICU patients was an acute respiratory failure and the prevalent associated diseases among patients with LC were systemic arterial hypertension, heart disease, and diabetes mellitus. The 
latter is one of the main causes of interference in the wound healing processes since the patient has a compromised immune system and is more prone to the occurrence of infections ${ }^{15}$.

Some harmful health habits, such as alcoholism, smoking, inadequate food, and sedentary lifestyle, are closely linked to the occurrence of chronic noncommunicable diseases and skin lesions ${ }^{13}$. Other factors that cause changes in the healing process are chronic diseases, age, and treatment with antineoplastic agents ${ }^{13}$. In the study, the minority of the patients were alcoholic and smoker.

The occurrence of the six lesions per medical adhesive of this study culminated with the change in the brand of the microporous tape used in the institution, besides the standardization of tape for sensitive skin, since the majority of the patients were elderly and submitted to neoadjuvant treatment.

Among the main causes for the appearance of friction lesions are the debilitated and totally dependent patients for activities of daily living, with impaired nutrition and mobility, friable skin, using corticosteroids, antiinflammatories and antihypertensives, elderly people and in palliative care ${ }^{6,11,12,17}$.

IAD is an inflammatory process caused by damage of the water-lipid-protein matrix of the skin resulting from prolonged exposure to the irritative agen $\mathrm{t}^{16}$, its occurrence is related to age, cancer, number of diaper changes per day, erythema, use of hypnotics/sedatives, antipsychotics, chronic diseases, double incontinence, fecal incontinence, impaired oxygenation, fever, malnutrition, decreased perfusion and oxygenation, cutaneous alterations and age $^{1}$. Most of these factors were present in participants in the ICU study and the incidence of IAD was $20.8 \%$.

Different data were found in a national study performed with critical patients in a private hospital in Paraná. The incidence of IAD was $15.27 \%$, with the majority of patients over 60 years of age and female ${ }^{18}$. However, in a study carried out in a general ICU with 145 adult patients, the author identified an incidence of $26.2 \%$ of IAD and an average time of 14 days for its appearance. The majority of the patients were males and the median age 69 years $^{19}$.

The results of this study corroborate another whose results confirmed that $87 \%$ of white female patients developed $\mathrm{IAD}^{16}$. Black skin appears to be a protective factor of skin lesions, because of its thickness, which makes it more resistant ${ }^{10}$.
In the long-stay institution scenario, the incidence of ICD was $8 \%$ lower than that obtained in this study ${ }^{20}$.

Most of the study patients were on urinary incontinence devices, such as a bladder catheter and a disposable diaper. These data were also present in the Brazilian study with adult patients to evaluate the main technologies applied by the nursing team in urinary control, which identified that $60 \%$ of the patients used diapers, followed by drainage by intermittent catheterization (24.8\%), ${ }^{21}$.

The skin of the perineal region of all patients was sanitized during diaper changes with water plus neutral soap. The continuous use of neutral soaps and other substances for hygiene causes changes in the barrier structure of the skin, which leads to dryness, in addition to increasing the $\mathrm{pH}$ of the skin, which is slightly acidic ${ }^{5}$.

The friction of the skin to remove irritating residues, such as ointments, oily creams, and oils, also causes disturbances in the barrier function of the skin through mechanical action ${ }^{5}$. That is, in addition to the aggression of the skin of the sample patients with urine and feces contact, there was also aggression by the product used for hygiene and friction to remove essential fatty acids and zinc oxide ointment.

In the study, it was identified that the majority of participants used a disposable diaper, which was changed four times a day, even in patients with more episodes of liquid feces per day. This action is related to the contract with supplementary health, however, when the diaper region is kept exposed to contact with the urinary and intestinal eliminations, it increases the risk of the patient developing ICD.

The international consensus on ICD classifies as skin protectors only vaseline-based ointment (not available in Brazil), dimethicone and liquid acrylate 4 . However, many study participants used the essential fatty acids to prevent dermatitis, although this product is classified as an emollient and should only be used to prevent loss of moisture by the skin ${ }^{5}$.

More: essential fatty acids are absorbed by the disposable diaper as well as any liquid substance, reducing the ability to absorb effluents and keeping the skin exposed to moisture for a longer period. In the present study, essential fatty acids were used indiscriminately, even mixed with other products, which may have contributed to the maintenance of skin exposed to moisture for a longer period.

The study had limitations related mainly to its casuistry, in addition to being performed in only one hospital specialized in oncology, with a collection time of only one month, which 
also made it difficult to perform more robust statistical analyses. Because it is a pilot study, it is intended, in the next step, to collect data for 12 months, maintaining a 30-day follow-up. It is recommended to replicate this research in other oncological hospitals since incidence studies will allow evaluating the predictive factors for the occurrence of $\mathrm{CL}$ in this clientele.

The knowledge produced with the accomplishment of this study could contribute to the strengthening of the clinical practice of nurses in the evaluation of their patients and in the differentiation of the CLs of the PIs.

\section{CONCLUSION}

The incidence of CLs was high (35.6\%) in oncologic patients admitted to the ICU, which is related to the presence of cancer and neoadjuvant treatment, which requires specific studies for elucidation. The IADs, the medical adhesive lesion, and the FL were considered as CLs, with a respective incidence of 20.8, 8.9 and 5.9\%. All participants used some type of adhesive and device for incontinence. The lesions appeared on average 11 days after ICU admission. It was also possible to describe the demographic and clinical profile of the patients in the sample and to characterize the lesions and surrounding skin.

\section{AUTHORS'CONTRIBUTION}

Conceptualization, Pires Júnior JF and Borges EL; Methodology, Pires Júnior JF and Borges EL; Research, Pires Júnior JF and Borges EL; Writing - First version, Pires Júnior JF; Borges EL and Spira JAO; Writing Reviewing and Editing, Pires Júnior JF; Borges EL and Spira JAO; Supervision, Borges EL.

\section{REFERENCES}

1. Gray M, Black JM, Baharestani MM, Bliss DZ, Colwell JC, Goldberg M, et al. Moisture-associated skin damage. J Wound Ostomy Continence Nurs. 2011;38(3),233-41. https://doi.org/10.1097/won.0b013e318215f798.

2. National Pressure Ulcer Advisory Panel. Pressure ulcer stages revised [Internet]. Washington, DC: NPUAD; 2016. [cited 14 Feb 2019]. Available at: http://www.npuap.org/ resources/educational-and-clinical-resources/npuappressure-injury-stages/.

3. Caliri MHL, Santos VLCG, Mandelbaum MHS, Costa IG. Classificação das lesões por pressão - Consenso NPUAP 2016 - Adaptada culturalmente para o Brasil [Internet]. São Paulo: Associação Brasileira de Estomaterapia/ Associação Brasileira de Enfermagem em Dermatologia; 2016 [cited 14 Feb 2019]. Available at: http://www. sobest. org.br/textod/35

4. Ministério da Saúde (BR). Portaria No 529 de 01 de abril de 2013 [Internet]. Brasília, DF; 2013. [cited 16 Jul 2016]. Available at: http://bvsms.saude.gov.br/bvs/saudelegis/g m/2013/prt0529 0104 2013.html

5. Beeckman D. A decade of research on incontinenceassociated dermatitis (IAD): evidence, knowledge gaps and next steps. J Tissue Viability. 2016;26(1):47-56. https://doi. org/10.1016/j.jtv.2016.02.004

6. Strazzieri-Pulido KC, Peres GR, Campanili TC, Santos VLG. Incidence of skintears and riskfactors: a systematic literature review. J Wound Ostomy Continence Nurs. 2017;44(1):2933. https://doi.org/10.1097/WON.0000000000000304

7. McNichol L, Lund C, Rosen T, Gray M. Medical adhesives and patient safety: state of the science: consensus statements for the assessment, prevention, and treatment of adhesive-related skin injuries. J Wound Ostomy Continence Nurs. 2013;32(5):365-80. https://doi. org/10.1097/NOR.0b013e3182a39caf.
8. Konya C, Sanada $H$, Sugama J, Okuwa M, Kamatani $Y$, Nakagami G, et al. Skin injuries caused by medical adhesive tape in older people and associated factors. J Clin Nurs. 2010;9(10):1236-42. https://doi.org/10.1111/j.1365-2702. 2009.03168.x

9. Ratliff, CR. Descriptive study of the frequency of medical adhesive-related skin injuries in a vascular clinic. J Vasc Nurs. 2017;35(2):86-9. https://doi.org/10.1016/j.jvn.2017.01.001

10. Strazzieri-Pulido KC, Peres GRP, Campanili TCGF, Santos VLCG. Skin tear prevalence and associated factors: a systematic review. Rev Esc Enferm USP. 2015;49(4):674-80. https://doi.org/10.1590/50080-623420150000400019

11. LeBlanc K, Christensen D, Cook J, Culhane B, Gutierrez O. Prevalence of skin tears in a long-term care facility. J Wound Ostomy Continence Nurs. 2013;3(40):580-4. https://doi. org/10.1097/WON.0b013e3182a9c111

12. Koyano $Y$, Nakagami G, lizaka S, Minematsu T, Noguchi $H$, Tamai $\mathrm{N}$, et al. Exploring the prevalence of skin tears and skin properties related to skin tears in elderly patients at a long-term medical facility in Japan. Int Wound J. 2014;13(2):189-97. https://doi.org/10.1111/iwj.12251

13. Amaral AFS, Pulido KCS, Santos VLCG. Prevalence of skin tears among hospitalized patients with cancer. Rev Esc Enferm USP. 2012;46(Espc):44-50. https://doi.org/10.1590/ $\underline{\text { S0080-62342012000700007 }}$

14. Machry VR, Susin CF, Barros RC, Lago LD. Desnutrição em pacientes com câncer avançado: uma revisão com abordagem para o clínico. Rev AMRIGS. 2011;55(3):296301. https://doi.org/10.1590/S0080-62342012000700007

15. Ramneesh G, Sheerin S, Surinder S, Bir S. A prospective study of predictors for post laparotomy abdominal wound dehiscence. J Clin Diagn Res. 2014;8(1):80-3. https://doi. org/10.7860/JCDR/2014/7348.3921 
16. Bliss DZ, Savik K, Thorson MA, Ehman SJ, Lebak K, Beilman G. Incontinence-associated dermatitis in critically ill adults. J Wound Ostomy Continence Nurs. 2011;38(4),433-45. https://doi.org/10.1097/WON.0b013e318220b703

17. Holmes RF, Davidson MW, Bonnie J. Skin tears care and management of the older adult at home. Home Healthcare Nurse. 2013;31(2):90-101. https://doi.org/10.1097/ NHH.0b013e31827f458a

18. Baessa CEB, Meireles VC, Balan MAJ. Ocorrência de dermatite associada à incontinência em pacientes internados na unidade de terapia intensiva. ESTIMA, Braz J Enterostomal Ther. 2014;12(2) [cited 30 Nov 2017]; Available at: https://www.revistaestima.com.br/index.php/ estima/article/view/89
19. Valls-Matarín J, Del Cotillo-Fuente M, Ribal-Prior R, PujolVila M, Sandalinas-Mulero I. Incidence of moistureassociated skin damage in an intensive care unit. Enferm Intensiva. 2017;28(1):13-20. https://doi.org/10.1016/j. enfi.2016.11.001

20. Campbell JL, Coyer FM, Osborne, SR. Incontinenceassociated dermatitis: a cross-sectional prevalence study in the Australian acute care hospital setting. Int Wound J. 2014;13(3):403-11. https://doi.org/10.1111/iwj.12322

21. Bitencourt GR, Alves LAF, Santana RF. Practice of use of diapers in hospitalized adults and elderly: cross-sectional study. Rev Bras Enferm. 2018;71(2):343-9. https://doi. org/10.1590/0034.7167-2016-0341 